\title{
Historein
}

Vol $13(2013)$

Questions and Orientations in History during the last 20 years. Part 2

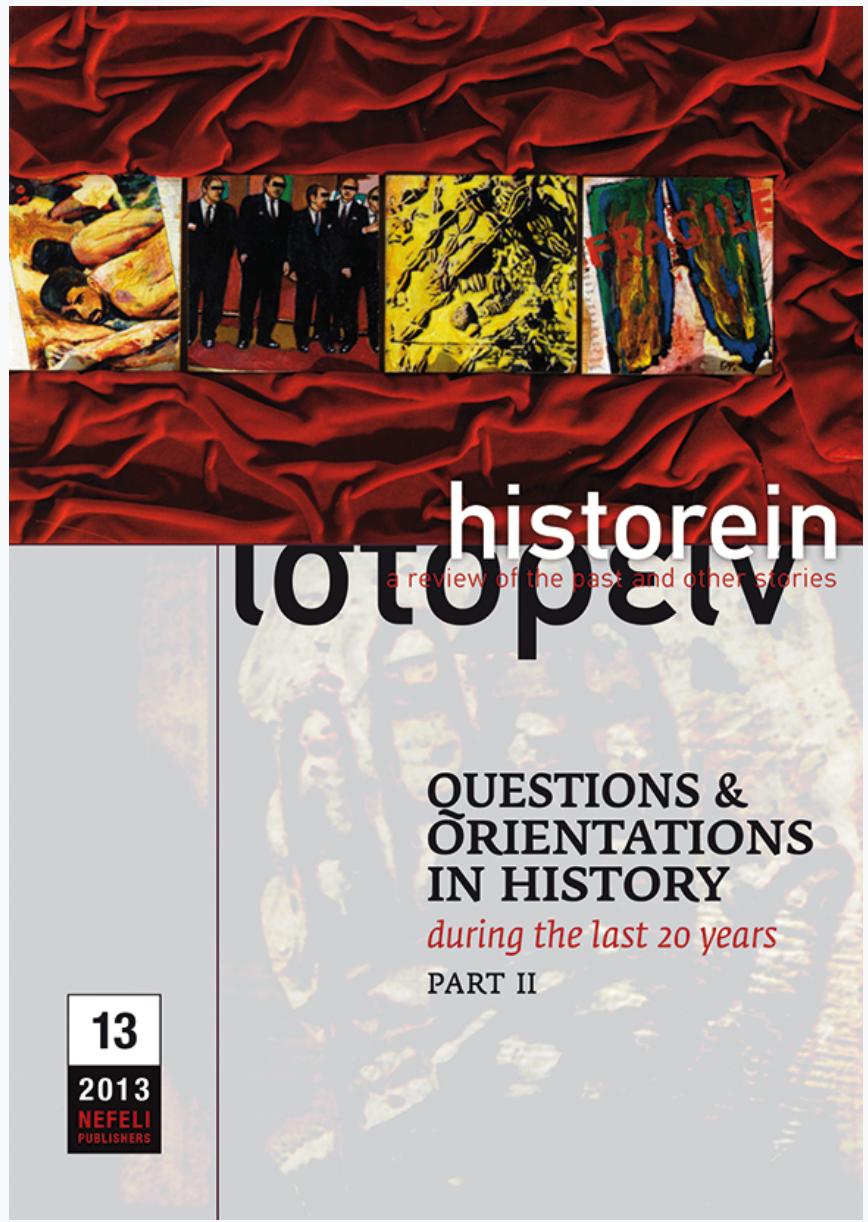

\section{Review of Joakim Radkau's Wood: A History}

Vaso Seirinidou

doi: $\underline{10.12681 / \text { historein.180 }}$

Copyright @ 2014, Vaso Seirinidou

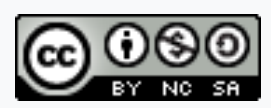

This work is licensed under a Creative Commons Attribution-NonCommercialShareAlike 4.0.

To cite this article:

Seirinidou, V. (2013). Review of Joakim Radkau's Wood: A History. Historein, 13, 114-118.

https://doi.org/10.12681/historein.180 
One of the strong points of the volume is its transnational scope, which allows for an overall understanding of public health developments in southeastern Europe. Nevertheless, generalisations are not easy to make, as different contexts shaped different discourses and policies of modernisation and health. For this reason, the authors should have elucidated further, as Bucur stresses, as to what is meant by a number of common terms, which possibly did not have common meanings in each regional context. What could also be explored further is the relationship of eugenics and hygiene with mental illness and psychiatry. Apart from a limited number of references, mainly by Mircheva and Turda, a series of important issues in the history of hygiene and eugenics are not analysed, such as Bénédict Morel's theory of degeneration, the problem of mental retardation and the development of the mental hygiene movements in the USA and western Europe. A final point deserving of mention is the persistence of eugenics, albeit transformed, after the second world war. As Trubeta notices, in Greece the Eugenics Society was founded in 1953 and parliamentary discussions about prenuptial certification took place not only in the first part of the twentieth century, but also in 1958 and 1962.

All in all, this volume is an excellent example of the potential of the social history of medicine. Based on new types of sources and on the theoretical premise that scientific knowledge and practice are in constant interplay with the social environment, the social history of medicine can generate new and exciting understandings of broader developments in society.

\section{Joachim Radkau}

\section{Wood: A History}

\section{Cambridge: Polity Press, 2012. 399 pp.}

\section{By Vaso Seirinidou}

University of Athens

Joachim Radkau's Wood: A History gets us back to basics, to the fundamental materials of human existence and the fundamental concerns of human societies. The book is about the interaction between wood and humans throughout history. It is a "tribute" to a material that, although it has marked human culture from the Stone Age to the early stages of industrialisation, has barely been transformed into a subject of historical narrative. However, the importance of Wood lies not mainly in the historical rehabilitation of a neglected material, but rather in the historisation of the actual global concern about the ways societies deal with limited resources.

The book appeared first in German (in 2007) as the third volume in the Stoffgeschichten (Material' histories) series published by the Wissenschaftszentrum Umwelt (Environment Science Centre) of Augsburg University and, as the original German title indicates, it is not primarily a history of wood (as the English translation leads us to assume), but rather a history through wood. Radkau, a professor of history at Bielefeld University and pioneering figure of European environmental history, integrates his early research on German forest history in the eighteenth century and the global approach of his later work Nature and Power (first published in German in 2000) into an ambitious "big history" that puts wood, its natural properties and human attitudes towards it at the centre of the understanding of the coevolution of man and nature. 
Setting the frame of his history in the first part of the book, Radkau reintroduces Werner Sombart's notion of the preindustrial age as a "Wooden Age", an era with a certain degree of inner unity deriving from the fact that wood constituted the key substance for fuel energy, construction and craftsmanship. But unlike Sombart, he is critical of seeing the decline of "wooden civilisation" as result of its inherent ecologically and economically vulnerable character, reflected in the antinomy between the abundant use of wood, as a condition for growth in preindustrial economies, and the finite nature of the resource. On the contrary, for Radkau it is precisely the omnipresence of scarcity and need that oriented societies towards more sustainable uses of wood and set bounds to unlimited economic growth. This "wood brake", as he designates it, was a component of ecological stability and ensured the maintenance of the traditional economic and social order.

Against the romanticised view of the preindustrial world as one of harmonic coexistence of man and forest and its degradationist counterpart, the depiction of forest history as one of gradual deforestation, Radkau proposes a history of interaction between man and wood that encompasses struggles over resource control, crises, catastrophes, but also arrangements between competing interests and dayto-day dealing with frugality and limitation. The emphasis of the book lies in the moments when this history became a dramatic narrative, namely on these moments when scarcity - real or not - became a problem that caused interventions that changed not only the traditional forms of forest economy but also the forest ecosystem itself.

The first dramatic undertones in the man and forest relationship began to take shape in the sixteenth century, when the wood shortage was first thematised as a problem requiring solutions. The second part of the book offers a detailed account of the historical conjunctures and processes that rendered the sixteenth century into a turning point in the history of man and wood. Going back to the high middle ages, Radkau sees in the forest regulations of the princely or communal courts the early expressions of an awareness of the finite nature of forest and of a mobilisation for its conservation. Although the late medieval period experienced large-scale clearances, planning and regulation began to appear more and more as principles for the authorities dealing with forests. Forest conservation, conceived as the restriction of access and use rights in the forest, became thus a policy matter, around which both lordship and communal structures were developed.

However, wood shortage as an issue of public concern would be thematised only after the sixteenth century. Radkau situates this development at the crossroads between the early capitalist expansion and the formation of the absolutist state. From the sixteenth century, the beginnings of the world maritime trade, the boom in housing construction in the European capitals and the explosion of the mountain mining industry brought a sharp rise in timber consumption. The ongoing commodification of timber implied a rehierarchisation of the uses of the forest at the expense of livestock grazing, whereas the emergence of modern concepts of property questioned traditional forestuse rights. The above process was reflected in the stream of forest ordinances issued in western and central Europe in the sixteenth century. Compared to their medieval equivalents, which were locally bounded, these new regulations indicated the ambition of the absolutist state to absorb the various rights into a single authority covering the whole territory. Complaints about wood shortages served to 
legitimate state intervention in the forest and the exclusion of traditional groups of users in favour of more profitable timber consumers.

Radkau goes further by examining the effect of the sixteenth-century wood shortage within the specific context of the early modern European economy. In his view, it was rather unrestricted growth than a wood shortage that tended to cause crisis symptoms in the mining sector in central Europe and to push up the cost of living. Radkau reminds us here about the historicity of "growth" as the constitutive principle of the capitalist economy, arguing that for the early modern societies as a whole the "wood brake" brought about by the metal frenzy contributed more to stability than to crisis. Sustainable forestry arose thus in central European mining regions from the sixteenth century in response to economic and ecological constraints. On the other hand, scarcity, in combination with the high cost of wood transportation, made the mining sector location-dependent. Unlike the industrial conglomerates of the nineteenth century, decentralisation in pursuit of wood and water was the distinctive mark of early forms of industrialisation.

At the turn of the eighteenth to the nineteenth centuries, the relationship between man and forest underwent dramatic changes in western and central Europe. As a supplier of timber, the forest was integrated into the mechanisms of the capitalist economy and rentability became the driving force of forestry. The emergence of forest science in the late eighteenth century came in response to the demand for rational and economical use of the forest, through planning and calculation. Official policy on forests was manifested not only in the increasing restriction of access and the criminalisation of some of the most common uses in the past, but also in the intervention, with the help of scientific forestry, in the forest ecosystem itself through regulation of rotation times and largescale reforestation with conifers. Wood scarcity, according to Radkau, was the link between these developments and the means that legitimated the establishment of new institutions in the forest.

Radkau's critical approach to the eighteenthcentury wood shortage dates back to the early 1980s, when he challenged the thesis that a real lack of timber existed in the German states. This fuelled a vivid debate among German historians, in what became known as the Holznotdebatte. Thirty years later, he unfolds his core argumentation, enriched by the findings of the Holznotdebatte, in the third part of this book. On the one hand, Radkau points out the various interests that lay behind the complaints over the wood emergency found in late eighteenth-century written sources. Scarcity not only legitimated the enforcement of the state's control of the forest, but also favoured the establishment of the newly emerged forest science, whereas the shortage of firewood was an argument in the hand of the communities against the restriction of their traditional forest-use rights. On the other hand, he extends the "wood brake" argument to the late eighteenth-century economy and relativises the notion of the wood crisis. He argues that wood scarcity symptoms did not result from the exhaustion of forest reserves, but rather from the penetration of the free market in the firewood sector. If in the premodern moral economy the ensuring of low firewood prices was a duty of the authorities towards the poor, in the new context rising prices were seen as the most effective means against wood shortages.

Furthermore, Radkau discusses wood scarcity from the point of view of technical innovation and change. In the eighteenth century, traditional recipes and new inventions, from 
the use of the saw instead of the axe in felling timber to the invention of the thermometer and the theory of combustion, were put to the service of saving wood. But as Radkau notices, these inventions, "children of necessity" as they were, could not affect the existing systems of production until new doctrines of economic behaviour came to the fore with the advance of industrialisation. At the beginning of the nineteenth century, the mass shift to coal, which for centuries had served as a local substitute for charcoal, was not only a response to the wood supply shortage but also signified a transition from an economy of limitations to an economy of growth, which was supposed to be unlimited due to the infinite "subterraneous forest of coal".

Radkau identifies the end of the wood age with the time from which "the natural properties of wood played less and less of a role in shaping workmen's skill, business locations and the pace of economic life" (236-37). This moment did not coincide with the beginning of the industrial revolution, which was a highpoint for wood-based technology. A decisive step towards the new era was the replacement of wood with iron in the production of machine tools around the 1820s. Primarily, the end of the wood age was a turning point in the history of labour, since it meant the loss of skill, versatility and autonomy associated with the craft of wood.

In the fourth part of the book, Radkau deals mainly with changes in technology and the organisation of labour in the wood sector in the high industrial age. He presents the different ways forestry developed in central Europe and north America. Whereas in the United States the mechanisation of logging and timber processing began in the second half of the nineteenth century, in central Europe the introduction of chainsaws and debarkers began in the early 1960s and the processing of wood maintained for a long period its craft character. Previously, the intensification of forestry in Germany was achieved through spruce monoculture, a method that referred to the glory days of pioneering nineteenth-century German forestry. The increasing role of wood waste in industry and the rise of engineered timber was the final blow to the craft structures of the timber sector in central Europe.

In the last chapters of the fourth part, Radkau discusses the new positions and meanings wood and forest have acquired since the 1970s and the emergence of the global concern for the environment. If industrialisation banished wood to the margins of economic, political, and cultural life, the eco-age made it again a public issue. Age-old fears concerning the "death of the forest" and the exhaustion of wood supplies have returned, while, at the same time, the forest as a renewable energy resource has become the new investment paradise. Old dichotomies concerning concepts of forestry and protection have moved anew to the fore, while sustainability, a notion that originates in the old German forestry term Nachhaltigkeit, has since the Rio Earth summit of 1992 become the leitmotiv of the world capitalist economy and global environmental policy. Radkau remains sceptical about the alarm over the "death of the forest" as well as to the applicability of generalising concepts in forest protection. In his view, historical insight might offer more flexible and sophisticated ways of thinking about the forest and acting for its protection.

In the fifth and last part of the book, Radkau broadens his geographical scope by including cases from Asia. In his short tour of the different experiences of forest management in Japan, China, India and Nepal, he grasps the opportunity to rethematise the connection be- 
tween forest and power and to substantiate the argument that runs through the whole of his book that "forest conservation is successful only when it coincides at least partially with the interests of the people living there and the concepts they have of legal rights" (325).

In this book, Radkau has succeeded in integrating forest history, the history of technology, the history of labour and social and cultural history into a cohesive history of the interaction between man and wood. As a trial in "big history", the book has a deficit in detailed documentation - almost inherent to such ambitious undertakings - especially in quantitative facts that could support author's main arguments about wood scarcity and the "wood brake". In general, the perspective of economic history is rather weak. On the other hand, Radkau's claim for a "global history of the coevolution of man and nature" seems not to have been accomplished here. His focus is German, with some British and North American references. The global "essence" of the last part is more geographical than historical, since Asian experiences are treated separately and not in their interconnection with the European ones.

What makes Wood extremely relevant is that it offers us the impetus to think critically about natural resources. In this sense, it is a highly political book. Radkau shows that without scarcity, every commodification and control over a resource would lack its legitimising foundation. In the next scarcity alarm, we have to think about this seriously.

\section{Petros Pizanias (ed)}

\section{The Greek Revolution of 1821: A European Event}

\section{Istanbul: Isis Press, 2011}

\author{
By Vasiliki Amorati \\ Boğaziçi University
}

The Greek revolution of 1821 has been documented in multiple personal narratives and testimonies, especially by people who lived during those years, people who were the protagonists of these events. Vivid memoirs and descriptions, including personal diaries written in an authentic style by the people who fought in the Greek lands against the Ottomans, and by foreigners, who either took up arms or supported the revolution through philhellenic movements, started to circulate immediately after the establishment of the first Greek independent state. However, in recent decades, there has been little academic historical research efforts and studies on the Greek war of independence and what has appeared mainly involves biographical analyses and anthropocentric stories.'

Generally speaking, the research interests of historians specialising on 25 March 1821, when the banner of revolution was raised against the Ottoman Empire and the story of "modern Greece" is usually said to have begun, have been around the protagonists - the heroes and their heroic acts before, during and even after the revolutionary war, neglecting numerous issues relating to the period. With this perspective in mind, The Greek Revolution of 1821: A European Event, edited by Petros Pizanias, brings together the work of scholars in the hope of facilitating a more transparent discourse. Taking this into consideration, and at the same time moving beyond the military 